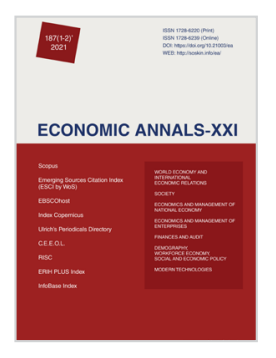

ECONOMIC ANNALS-XXI

ISSN 1728-6239 (Online)

ISSN 1728-6220 (Print)

https://doi.org/10.21003/ea

http://www.soskin.info/ea/

Volume 187 Issue (1-2)'2021

Citation information:

Arifuddin, M., Darwis, S., \& Sundari, S. (2021). Behaviour models of audit quality reduction associated with auditor's work stress. Economic Annals-XXI, 187(1-2), 215-222. doi: https://doi.org/10.21003/ea.V187-21

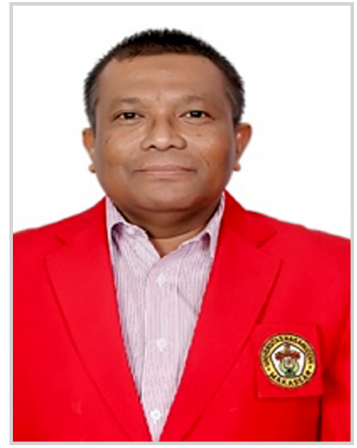

Mannan Arifuddin

PhD (Economics), Professor,

Department of Accounting,

Faculty of Economics and Business,

Hasanuddin University

Jl. Perintis Kemerdekaan Km.10 Makassar,

90245, South Sulawesi Province, Indonesia

arifuddin.mannan@gmail.com,

goz.mr@yahoo.com

ORCID ID:

https://orcid.org/0000-0003-0410-4598

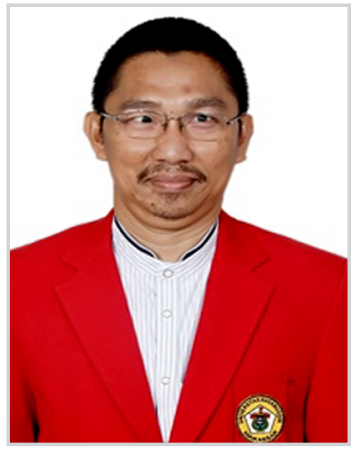

Said Darwis

PhD (Economics), Associate Professor, Department of Accounting,

Faculty of Economics and Business, Hasanuddin University

Jl. Perintis Kemerdekaan Km.10 Makassar, 90245

South Sulawesi Province, Indonesia darwissaid@yahoo.com ORCID ID:

https://orcid.org/0000-0002-4232-4404

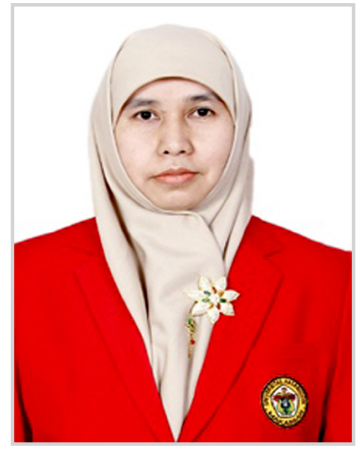

Sri Sundari

PhD (Economics), Associate Professor, Department of Accounting,

Faculty of Economics and Business, Hasanuddin University Jl. Perintis Kemerdekaan Km.10 Makassar, 90245, South Sulawesi Province, Indonesia sriamir66@yahoo.com ORCID ID:

\title{
Behaviour models of audit quality reduction associated with auditor's work stress
}

\begin{abstract}
The current study's main aim is to examine a behaviour model of reducing audit quality in relation to auditor work stress. The study was performed in 2020 and the cases in the current research were auditors of the Audit Board of the Republic of Indonesia (BPK), auditors of the Development Finance Audit Board (BPKP) and public accounting firm (KAP) auditors in South Sulawesi Province. The sample numbers is determined according to the sample size needed via data investigation employing the Partial Least Square approach, using a random sampling method. The data collected by utilizing a questionnaire and questionnaire data, which can be analyzed as many as 97 . The output of this study indicate: (1) the long period pressure cause increase auditor working stress; (2) the long period pressure cause the reduction of audit quality behaviour; (3) the long period conflict cause increase auditors' working stress; (4) the high role conflict cause increasement the audit quality reduction behaviour; (5) external locus of control cause increasement auditors' working stress; (6) external locus of control will increase audit quality reduction behaviour, and (7) high work stress cause reduction of audit quality behaviour.
\end{abstract}

Keywords: Time Pressure; Role Conflict; External Locus of Control; Auditor Work Stress; Audit Quality Reduction Behaviour

JEL Classifications: M12; M42; M54

Acknowledgements and Funding: The authors received no direct funding for this research.

Contribution: The authors contributed equally to this work.

DOI: https://doi.org/10.21003/ea.V187-21

\section{Аріфуддін М.}

кандидат економічних наук, професор, кафедра бухгалтерського обліку, факультет економіки та бізнесу, Університет Хасануддін, Макассар, Індонезія

\section{Дарвіс C.}

кандидат економічних наук, доцент, кафедра бухгалтерського обліку, факультет економіки та бізнесу, Університет Хасануддін, Макассар, Індонезія

\section{Сундарі ш.}

кандидат економічних наук, доцент, кафедра бухгалтерського обліку, факультет економіки та бізнесу, Університет Хасануддін, Макассар, Індонезія 


\section{Поведінкові моделі зниження якості аудиту, пов'язані зі стресом аудитора}

Анотація. Основна мета дослідження - вивчити поведінкову модель зниження якості аудиту в умовах стресу аудитора на роботі. Дослідження було проведено в 2020 році, і його учасниками були аудитори Аудиторської ради Республіки Індонезія (ВPK), аудитори Аудиторської ради щодо фінансування розвитку (BPKP) й аудитори державної бухгалтерської фірми (KAP) у провінції Південний Сулавесі. Дані були зібрані за допомогою 97 анкет. Результати цього дослідження показують, що: 1) висока нестача часу збільшує навантаження на аудитора; 2) скорочення термінів приведе до зниження якості аудиту; 3) високий рольовий конфлікт збільшить робочий стрес аудиторів; 4) високий рольовий конфлікт призведе до поведінки, що знижує якість аудиту; 5) зовнішній локус контролю збільшує навантаження на аудиторів; 6) зовнішній локус контролю підвищить поведінку, пов'язану зі зниженням якості аудиту; 7) високий робочий стрес підвищить поведінку щодо зниження якості аудиту.

Ключові слова: аудитор; аудит; тиск часу; конфлікт ролей; зовнішній локус контролю; стрес аудитора на роботі; поведінка; зниження якості аудиту.

\section{Арифуддин М.}

кандидат экономических наук, профессор, кафедра бухгалтерского учета, факультет экономики и бизнеса, Университет Хасануддин, Макассар, Индонезия

Дарвис C.

кандидат экономических наук, доцент, кафедра бухгалтерского учета, факультет экономики и бизнеса, Университет Хасануддин, Макассар, Индонезия

\section{Сундари Ш.}

кандидат экономических наук, доцент, кафедра бухгалтерского учета, факультет экономики и бизнеса, Университет Хасануддин, Макассар, Индонезия

\section{Поведенческие модели снижения качества аудита, связанные со стрессом аудитора}

Аннотация. Основная цель настоящего исследования - изучить поведенческую модель снижения качества аудита в отношении стресса аудитора на работе. Исследование было проведено в 2020 году, и его участниками были аудиторы Аудиторского совета Республики Индонезия (ВРК), аудиторы Аудиторского совета по финансированию развития (ВРКР) и аудиторы государственной бухгалтерской фирмы (KAP) в провинции Южный Сулавеси. Данные были собраны с помощью 97 анкет. Результаты этого исследования показывают, что: 1) высокая временная нехватка увеличивает нагрузку на аудитора; 2) сжатие сроков приведет к снижению качества аудита; 3) высокий ролевой конфликт увеличит рабочий стресс аудиторов; 4) высокий ролевой конфликт приведет к поведению, снижающему качество аудита; 5) внешний локус контроля увеличивает нагрузку на аудиторов; 6) внешний локус контроля повысит поведение, связанное со снижением качества аудита; 7) высокий рабочий стресс повысит поведение по снижению качества аудита.

Ключевые слова: аудитор; аудит; давление времени; конфликт ролей; внешний локус контроля; стресс аудитора на работе; поведение; снижение качества аудита.

\section{Introduction}

An accountant is an accountancy specialist. By law, certain practitioners are given certain duties, including the right to verify a company's monetary accounts and be held accountable for professional wrongdoing. The profession of a public accountant, in this case, an auditor, is a professional accountant who sells his services to the general public, especially in the field of objective examination of a company's financial statements(Salehi Dashti, 2020). Public trust on financial reports that public accountants audit needs public accountants to pay close attention to audit quality (Ika and Suryani, 2019; Nugraha et al., 2020; Cahyono et al., 2021). However, the intense competition and increased demand for auditing raised concerns about the auditor's inability to meet audit quality. The auditor commits irregularities in the audit by taking shortcuts that have clearly violated the public accountant's code of ethics. Reduction in audit quality is regarded as a decrease in auditors' audit quality carried out deliberately (John, 2021). Malone and Robert s stated that the behaviour of reducing audit quality is the action taken by the auditor when carrying out an audit program which results in a reduction in the efficiency of audit confirmation that must be collected (Malone and Roberts, 1996; Suresh et al., 2021). Such behaviour negatively impacts the audit report results late because of the audit evidence's completeness during the audit into doubt the auditors' reliability express an idea on the client's economical statements. Such is thecase with the falsification of BPKP audit results in the corruption case of provincial grant funds for the Election Supervisory Board (BAWASLU) in East Java in 2013.

The formulation of the problem in this study is trying to prove the existence of a relationship between the factors that cause auditors' work stress and their effect on the behaviour of reducing audit quality. The researchers' work and is expected to contribute theoretically and practically. Theoretically, this study's results are expected to add insight into the accounting literature 
kep e rilakuan especially in auditing-related factors that affect job stress, and audit quality reduction behaviour. In practical terms, the results of this study are expected to provide benefits to the leaders of BPK, BPKP and KAP in South Sulawesi Province in assessing strategies to produce a helpful work environment and build an organizational knowledge that can align anticipations and professional needs so as to decrease pressure encountered by auditors in carrying out their work and mitigating the possibility of auditors carrying out practices/behaviours to reduce audit quality.

\section{Methodology}

\subsection{Research Design}

Based on the research objectives and conceptual framework, this research is an explanatory study, which is a form of research that will explain the relationship between exogenous or independent variables consisting of time pressure, role conflict and locus of control. Meanwhile, the endogenous or dependent variables are job stress and audit quality reduction behaviour. The purpose of explanatory research is to explain the causal and correlational relationships between variables through hypothesis testing. This research utilizes a Partial Least Square (PLS) approach to analyze direct and indirect effects.

\subsection{Population and Sample}

The current survey was carried out in February 2020. The population in this study were auditors of the Audit Board of the Republic of Indonesia (BPK), auditors of the Development Finance Audit Board (BPKP), and Public Accounting Firm (KAP) auditors in South Sulawesi Province. The unit of analysis in the current research is auditors at all stages of the organizational hierarchy, namely junior/staff auditors, senior auditors, audit managers, and audit partners who are involved in the implementation of an audit program on financial statement audits with a minimum of 2 years of audit experience. This criterion was taken since, auditors who have audit experience of at least 2 years have been responsible for carrying out the audit program.

The selection of sample in the present research was carried out by a random approach. Sample selection is the determination of the research sample size. The number of samples is determined according to the sample size needed via data investigation employing the PLS approach. The number of samples needed to estimate the maximum likelihood with the PLS approach model ranges from 30 to 100 (Ghozali, 2008; khan \& John, 2021).

\subsection{Research Instruments}

The variables tested in this study were measured by the questions adopted from the instruments used in previous studies. The questionnaire's question design was baccording to the theoretical structure underlying the paper questions (Salehi Dashti, 2020). The questionnaire preparation should adequately consider all the data required to be replied the research queries and form an overall integration (Cahyono et al., 2021).

\subsection{Operational Definition and Measurement of Variables}

In this study, which included variable dependent is job stress and $p$ Behaviours reduction in audit quality, which is a variable that is influenced by factors such as t ekanan time, conflicting roles and locus of control, which in this study as independent variables.

Audit Quality Reduction Behaviour. Audit quality reduction behaviour is expressed as the auditor actions over the audit engagement that decrease the audit evidence's efficacy (Malone and Roberts, 1996). The behavioral indicators for reducing audit quality were adapted from Kelley and Margheim's research (Kelly et al., 1999) and Otley and Pierce (Otley and Pierce, 1996). The scale used is the Likert scale with five points $t$.

Job Stress. Job stress is presented as the response faced by a person when faced with demands or work that exceeds his ability, and this condition creates pressure in completing his job. Job stress is measured based on the antecedent variable of work stress, which in this study consisted of time pressure, role conflict and locus of control.

Time Pressure. Time pressure is a form of pressure that arises from the limited time resources given to complete the work. The indicators used in this study were adopted from Otley and Pierce (Otley and Pierce, 1996). The scale used is the Likert scale with five points. 
Role Conflict. Role conflict occurs when various demands from many sources cause employees to find it difficult to determine what demands must be met without making other demands ignored. Role conflict is measured based on an instrument developed. The scale used is a fivepoint Likert scale.

Locus of Control. Locus of control is a personality characteristic that describes a person's level of confidence about the extent to which they can control the factors that influence the success or failure they experience, in dictator using scale Likert with five points (John, 2021).

\subsection{Data Collection Techniques}

The data utilized in the current research are primary data, namely the respondents' answers to the questions on the research questionnaire. Methods of data collection are done by visiting the auditors directly in the Audit Board of the Republic of Indonesia (BPK), Development Finance Audit Board (BPKP), and public accounting firm (KAP) with the consideration over the accuracy of the results of the questionnaire and to me mperbesar return rate of questionnaires. In the data collection methods mentioned above, submitting questionnaires to respondents and collecting filled-out questionnaires from respondents is done either online or through contact persons.

\subsection{Data Analysis Techniques}

The present survey utilizes the Partial Least Square (PLS) approach in examining data. This is done because the sample used does not have to be large and can be utilized to confirm the theory and predict the correlation among latent variables (Suresh et al., 2021; Chin and Newsted, 1999). Data analysis using PLS is made up of two sub-models: the outer Model as well as the structural Model.

\subsubsection{Measurement Model}

The measurement model explains how the variable manifests or the detected variable. Outer Model is applied to test construct efficacy and instrument dependability. The efficacy test was managed to determine the research instrument's capability of measuring what must be assessed(Cahyono et al., 2021). An indicator is declared valid if it holds an AVE (average variance extracted) value above 0.50 or proves that the whole outer loading dimension variable has a loading value $>0.5$ or the highest loading factor value for the proposed construction as opposed to the loading factor value for different constructs so that it concludes these measurements meet the criteria of convergent validity (Chin and Newsted, 1999; Ghozali and Latan, 2015; John, 2021).

\subsubsection{Structural Model Evaluation}

The Inner Model (structural Model) is a model that reveals the potential of estimation among constructs or latent variables. Throughout the bootstrapping process, $T$-Statistical test parameters are collected to foresee the existence of a causal connection among these latent variables. Inner Model is estimated by studying the variance of variance explained via the $R$-Square amount and the structural path-coefficient for the association among the variables. If the $R$-Square value is greater than $0.75,0.5$, and 0.25 , it can be interpreted that the latent predictor has a strong influence, moderate and weak, at the level struct Ural (Ghozali and Latan, 2015; Salehi Dashti, 2020).

\section{Results}

\subsection{Data Description}

The object of the research is the auditors of the Audit Board of the Republic of Indonesia (BPK), Development Finance Audit Board (BPKP), as well as public accounting firm (KAP) in South Sulawesi Province. The unit of analysis in the present research is auditors at all stages of the organizational hierarchy, namely junior/staff auditors, senior auditors, audit managers, and audit partners who are involved in the implementation of an audit program on financial statement audits with a minimum of 2 years of audit experience.

The sample collection in the research was carried out through a random process. The characteristics of the respondents who were the samples of this study ar given in Table 1. 
Table 1:

Characteristics of Respondents

\begin{tabular}{|c|c|c|}
\hline Information & Total & Percentage \\
\hline Number of Samples & 97 & $100 \%$ \\
\hline Gender: & 64 & $66 \%$ \\
Male & 33 & $34 \%$ \\
Women & & \\
\hline Age: & 33 & $34 \%$ \\
$20-35$ & 43 & $44 \%$ \\
$36-50$ & 21 & $22 \%$ \\
$>51$ & & \\
Agency: & 24 & $25 \%$ \\
HOOD & 57 & $59 \%$ \\
BPKP & 16 & $16 \%$ \\
CPC & & \\
\hline
\end{tabular}

Source: Own research

Given Table 1, it can be observed that the quantity of male respondents is somewhat greater than female ones. The male number was 64 people (66\%) and women 33 people (34\%). Respondents aged over 20 years were 33 people (34\%), respondents aged 36-50 years were 43 people (44\%), and 21 (22\%) people were aged over 51 years. In addition, based on Table 1, it is known from KAP agencies as many as 24 people (25\%), BPKP as many as 57 people (59\%), and BPK as many as 16 people (16\%) who were research respondents.

\subsection{Data Analysis}

Data processing techniques utilizing the PLS technique in investigating data. Data analysis using PLS is made up of 2 sub-models: the measurement(outer) Model as well as the Structural Model, which is regularly named the inner Model (Ghozali and Latan, 2015; John, 2021). These stages are as follows:

\subsubsection{Descriptive Statistics}

Analysis of variable descriptions by interpreting the average value of each sub-variable (dimension) in the current survey intends to depict a picture of the dimensions that build the research model concept as a whole. The sample data processed in the survey were 97 . Descriptive data for all of the variables presented in Table 2.

\subsubsection{Assess the Outer Model or Measurement Model (Table 3)}

There are numerous standards in applying data analysis methods with SmartPLS to evaluate the outer models that convergent validity of measurement models can be inferred from the association among the indicators scores with a score variable. Evaluating the AVE (average variance extracted) value above 0.5 , or showing that the entire outer loading dimension variable has a loading value $>0.50$, or the highest loading value for the intended construct related to the loading value for the others (Chin and Newsted, 1999; Salehi Dashti, 2020).

Initially, the outer design value or association between a variable and construct doesn't satisfy the convergent validity since indicators have a loading value beless 0.60 . Model modification is performed by removing indicators that have a loading factor value less than 0.60 .

\subsubsection{Assessing Reliability and Average Variance Extracted}

The next step in measuring the outer Model of the measurement model is to assess the composite reliabilityand Cronbach's alpha. A statement item is guaranteed, so the Cronbach's alpha must be >0.60 (Ghozali and Latan, 2015; Cahyono et al., 2021).

Table 2:

Descriptive Data

\begin{tabular}{|c|c|c|c|c|c|}
\hline & $\mathbf{N}$ & Minimum & Maximum & Mean & Standard Deviation \\
\hline Time Pressure (X1) & 97 & 1 & 5 & 2.5700 & 0.70399 \\
\hline Role Conflict (X2) & 97 & 1 & 5 & 2.0968 & 0.56962 \\
\hline External locus of control (X3) & 97 & 1 & 5 & 3.6132 & 0.36966 \\
\hline Work Stress (Y1) & 97 & 1 & 5 & 2.0186 & 0.67890 \\
\hline Audit Quality Reduction Behaviour (Y2) & 97 & 1 & 5 & 2.4804 & 0.53476 \\
\hline Valid N (listwise) & 97 & & & & \\
\hline
\end{tabular}

Source: Processed Data, 2020 
In Table 4, the values of composite reliability, Cronbach Alpha, and AVE are presented for all variables.

Considering Table 4, we can infer that all of the constructs satisfy the standards for being reliable.

\subsubsection{Structural Model Testing (Inner Model)}

Inner (structural) Model express the correlation among latent variables on the basis of the substantive hypothesis. The Model's design struck Tural relations among latent variables on the basis of the problem formulation.

The variance percentage explained via the $R$-Square value and the structural path coefficient for the association among independent variables and the dependent ones. Variations in $R$-Square's value can be applied to describe the impact of specific exogenous latent variables on the endogenous latent variable, whether it has pengaru h or substantive relationship. If the $R$-Square value is greater than $0.75,0.5$, and 0.25 , it could be investigated that the latent predictors have a strong, moderate, and weak impact at the structural level (Ghozali and Latan, 2015; John, 2021).

Table 5 demonstrates that the $R$-square value is at a moderate level. The work stress variable is 0.468 ; this indicates that the independent variable in explaining the dependent variables is $46.8 \%$. The $R$-square variable of audit quality reduction behavior is 0.586 ; this indicates that the independent variable in defining the dependent variable is $58.6 \%$.

\subsubsection{Hypothesis test}

The importance of the predicted parameters presents beneficial knowledge regarding the connection among the variables of the survey. The foundation applied in examining the hypothesis is the value included in the output outcome for inner weight. Table 6 produces a predicted output for structural model testing.

\section{Table 3:}

The Outer Loading (Measurement Model)

\begin{tabular}{|c|c|c|c|c|c|c|c|}
\hline Variable & Contract & Early Model & Modify. & Variable & Contract & Early Model & Modify. \\
\hline \multirow{7}{*}{ Time Pressure } & $\times 1.1$ & 0.436 & - & \multirow{15}{*}{$\begin{array}{c}\text { Locus of Control } \\
\text { External }\end{array}$} & $\times 3.1$ & 0.738 & 0.776 \\
\hline & $\times 1.2$ & 0.498 & - & & $\times 3.2$ & 0.653 & 0.720 \\
\hline & $\times 1.3$ & 0.607 & 0.624 & & $\times 3.3$ & 0.728 & 0.759 \\
\hline & $\times 1.4$ & 0.700 & 0.734 & & $\times 3.4$ & 0.036 & - \\
\hline & $\times 1.5$ & 0.503 & - & & $\times 3.5$ & 0.686 & 0.744 \\
\hline & $\times 1.6$ & 0.837 & 0.873 & & $\times 3.6$ & 0.689 & 0.697 \\
\hline & $\times 1.7$ & 0.726 & 0.742 & & $\times 3.7$ & 0.282 & - \\
\hline \multirow{13}{*}{ Role Conflict } & $\times 2.1$ & 0.563 & - & & $\times 3.8$ & 0.027 & - \\
\hline & $\times 2.2$ & 0.703 & 0.651 & & $\times 3.9$ & 0.659 & 0.626 \\
\hline & $\times 2.3$ & 0.485 & - & & $\times 3.10$ & 0.735 & 0.693 \\
\hline & $\times 2.4$ & 0.245 & - & & $\times 3.11$ & 0.699 & 0.647 \\
\hline & $\times 2.5$ & 0.544 & - & & $\times 3.12$ & 0.340 & - \\
\hline & $\times 2.6$ & 0.713 & 0.708 & & $\times 3.13$ & 0.734 & 0.699 \\
\hline & $\times 2.7$ & 0.487 & - & & $\times 3.14$ & -0.135 & - \\
\hline & $\times 2.8$ & 0.754 & 0.797 & & $\times 3.15$ & 0.027 & - \\
\hline & $\times 2.9$ & 0.720 & 0.751 & \multirow{10}{*}{$\begin{array}{c}\text { Audit's Quality } \\
\text { Reduction Behaviour }\end{array}$} & Y2.1 & 0.761 & 0.799 \\
\hline & $\times 2.10$ & 0.510 & - & & Y2.2 & 0.686 & 0.727 \\
\hline & $\times 2.11$ & 0.715 & 0.740 & & Y2.3 & 0.717 & 0.739 \\
\hline & $\times 2.12$ & 0.699 & 0.736 & & Y2.4 & 0.685 & 0.723 \\
\hline & $\times 2.13$ & 0.766 & 0.796 & & $Y 2.5$ & 0.550 & - \\
\hline \multirow{5}{*}{ Work stress } & Y1.1 & 0.881 & 0.880 & & Y2.6 & 0.700 & 0.737 \\
\hline & Y1.2 & 0.810 & 0.809 & & Y2.7 & 0.373 & - \\
\hline & Y1.3 & 0.711 & 0.714 & & Y2.8 & 0.299 & - \\
\hline & Y1.4 & 0.879 & 0.880 & & Y2.9 & 0.363 & - \\
\hline & Y1.5 & 0.816 & 0.812 & & $\mathrm{Y} 2.10$ & 0.729 & 0.799 \\
\hline
\end{tabular}

Source: Processed Data, 2020

Table 4:

Construct Reliability Test

\begin{tabular}{|c|c|c|c|}
\hline Variables & Cronbach's Alpha & Reliability & Average Variant Extracted (AVE) \\
\hline$X 1$ & 0.735 & 0.834 & 0.560 \\
\hline$X 2$ & 0.863 & 0.895 & 0.550 \\
\hline$X 3$ & 0.879 & 0.900 & 0.502 \\
\hline Y1 & 0.879 & 0.912 & 0.675 \\
\hline Y2 & 0.849 & 0.888 & 0.569
\end{tabular}

Source: Processed Data, 2020 
Table 5:

Estimation of $\boldsymbol{R}$-Square

\begin{tabular}{|l|c|c|}
\hline \multicolumn{1}{|c|}{ Variables } & $\boldsymbol{R}$-Square & $\boldsymbol{R}$-Square Adjusted \\
\hline Y1 (Work Stress) & 0.468 & 0.451 \\
\hline Y2 (Audit Quality Reduction Behaviour) & 0.586 & 0.568 \\
\hline
\end{tabular}

Source: Processed Data, 2020

Table 6:

Result for Inner Weight

\begin{tabular}{|c|c|c|c|c|c|}
\hline Variable & Original Estimate & Mean & SD & $T$-Statistics & $P$-Values \\
\hline $\mathrm{XL}->\mathrm{YI}$ & 0.243 & 0.237 & 0.097 & 2.518 & 0.012 \\
\hline$X L->Y 2$ & 0.384 & 0.388 & 0.091 & 4.237 & 0.000 \\
\hline $\mathrm{X} 2->\mathrm{YI}$ & 0.448 & 0.452 & 0.123 & 3.652 & 0.000 \\
\hline$X 2->Y 2$ & 0.255 & 0.251 & 0.093 & 2.738 & 0.006 \\
\hline $\mathrm{X} 3->\mathrm{YI}$ & 0.232 & 0.242 & 0.079 & 2.925 & 0.004 \\
\hline$X 3->Y 2$ & 0.147 & 0.152 & 0.070 & 2.097 & 0.037 \\
\hline $\mathrm{Y} \mid->\mathrm{Y} 2$ & 0.225 & 0.213 & 0.107 & 2.100 & 0.036 \\
\hline
\end{tabular}

Source: Processed Data, 2020

In PLS, the statistical examination of each hypothesized connection is conducted utilizing a simulation. In this instance, the bootstrap technique is carried out over the sample. Bootstrapping measurement is meant to reduce the issue of abnormal data. The results are as follows:

Testing the influence of time pressure on auditor work stress shows the path-coefficient value of 0.243 . The value of $T$ received is 2.518 . This amount is more significant than $T$ table (1.986). This outcome implies that high time pressure is able to raise the auditors' work stress. So that the hypothesis $\mathrm{H} 1 \mathrm{a}$ is acquired.

Examining the influence of time pressure on the behaviour of reducing audit quality shows a path coefficient value of 0.384 . The $T$ value is 4.237 . The value is more than $T$ table (1.986). This effect indicates that high time pressure can raise audit quality reduction behavior to accept the H1b hypothesis.

Testing the impact of role conflict on auditor working stress shows the value of path coefficient 0.448 . The $T$ value is 3.652, which is greater than $T$ table (1.986). This result interpreted that the high role conflict will cause auditors' working stress. So that the hypothesis $\mathrm{H} 2 \mathrm{a}$ is accepted.

Testing the impact of role conflict on the behaviour of reducing audit quality shows a path coefficient of 0.255 . The $T$ value obtained is 2.738 . This value is greater than $T$ table (1.986). This result means that the high role conflict cause increment in the audit quality reduction behaviour. So the $\mathrm{H} 2 \mathrm{~b}$ hypothesis is corrected.

Results of testing the effects of locus of control are external to stress the work of auditors showed nil ai path coefficient of 0.232 . The $T$ value obtained is 2.925 , which is greater than $T$ table (1.986). This result interpreted that the locus of control external cause increment in the job stress auditor. So the hypothesis $\mathrm{H} 3 \mathrm{a}$ is accepted.

Testing the effect of time pressure on the behaviour of reducing audit quality shows a path coefficient of 0.147 . The $T$ value is 2.097 , which is greater than $T$ table (1.986). This result shows that locus of control externally will improve the behaviour of a reduction in audit quality. So the hypothesis $\mathrm{H} 3 \mathrm{~b}$ is accepted.

Testing the impact of work stress on auditors on audit quality reduction behaviour shows the path coefficient value of 0.225 . The $T$ value is 2.100 , which is greater than $T$ table (1.986). This result shows that high auditors' work stress will increase audit quality reduction behaviour. So that hypothesis $\mathrm{H} 4$ is accepted.

\section{Conclusion}

From the results of the tests that have been carried out in this study, it can be inferred that the overall hypothesis developed can be trusted, where the high time demand will expand the auditor's work stress; the high time pressure expand the audit quality reduction behaviour; the role conflict will increase job stress of auditor; the high level of role struggle will improve the audit quality reduction behaviour; Locus of control external auditors will increase work stress; Locus of control externally will improve audit quality reduction behaviour, and the high level of work stress will increase the audit quality reduction behaviour. This illustrates that the phenomenon of audit quality reduction behaviour is increasing. Meanwhile, the auditor profession is to provide audit 
services that are required to enhance the status of services provided. Hence, this research is important to do so that it becomes material for consideration or reference for local governments in supervising auditors in charge of supervising the implementation of finance and development in accordance with applicable regulations.

\section{References}

1. Cahyono, Y. T., Putri, D. A. W., \& Nurharjanti, N. N. (2021). The Audit Experience as a Moderating the Effect of E-Audit Implementation and the Audit's Working Environment on the Quality of Audit Findings in the Fraud Auditing. Riset Akuntansi dan Keuangan Indonesia, 5(3), 313-322. http://journals.ums.ac.id/index.php/reaksi/article/view/13597

2. Chin, W. W., \& Newsted, P. R. (1999). Structural equation modeling analysis with small samples using partial least squares. In R. H. Hoyle (Ed.), Statistical Strategies for Small Sample Research, (pp. 307-341). Thousand Oaks: CA: Sage Publications. https://www.scirp.org/(S(351jmbntvnsjt1aadkposzje))/reference/ReferencesPapers. aspx?ReferencelD $=448254$

3. Ghozali, I. (2008). Structural equation modeling. Metode Alternatif Dengan Partial Least Square. Semarang: Badan Penerbit Universitas Diponegoro. https://digilib.undip.ac.id/v2/2012/10/04/structural-equation-modelingmetode-alternatif-dengan-partial-least-square

4. Latan, H., \& Ghozali, I. (2015). Partial least squares: concepts, techniques and applications using the smart PLS 3. ( $2^{\text {nd }}$ edition). Universitity of Diponegoro Press. Semarang. Indonesia. https://www.springer.com/gp/ book/9783319640686

5. Ika, D., \& Suryani, Y. (2019). Analysis Of Competence, Independence And Professional Ethics Influence On Audit Quality (Empirical Studies Of Public Accountant Offices In Medan). Multi-Disciplinary International Conference University of Asahan, 1. http://jurnal.una.ac.id/index.php/seminter2019/article/view/543

6. khan, M. Jalal, \& John, J. A. (2021). Employee Stress Management Factors Influencing Selected Audit Firms in the Kingdom of Bahrain. iKSP Journal of Innovative Writings, 1(2). https://iksp.org/journals/index.php/ijiw/ article/view/59

7. Kelly, T., Margheim, L., \& Pattison, D. (1999). Survey on the differential effects of time deadline pressure versus time budget pressure on auditor behaviour. Journal of Applied Business Research (JABR), 15(4), 117-128. https://doi.org/10.19030/jabr.v15i4.5666

8. Malone, Ch. F., \& Roberts, R. W. (1996). Factors associated with the incidence of reduced audit quality behaviours. Auditing: a journal of practice \& theory, 15(2), 49-60. https://ssrn.com/abstract=2639

9. Nugraha, E., Nugroho, L., \& Setiawan, A. (2020). Discourses of determinants factor in audit quality. $1^{\text {st }}$ Annual Conference Economics, Business, and Social Sciences, ACEBISS 2019, 26-30 March, Jakarta, Indonesia. https://doi.org/10.4108/eai.26-3-2019.2290776

10. Otley, D. T., \& Pierce, B. J. (1996). Auditor time budget pressure: consequences and antecedents. Accounting, Auditing \& Accountability Journal, 9(1), 31-58. https://doi.org/10.1108/09513579610109969

11. Pierce, B., \& Sweeney, B. (2004). Cost-quality conflict in audit firms: an empirical investigation. European Accounting Review, 13(3), 415-441. https://doi.org/10.1080/0963818042000216794

12. Salehi Dashti, M., \& Saedi, R. (2020). Investigating the Effects of Work and Social Stress Factors on Job Performance of Auditors. Journal of Health Accounting, 9(1), 41-60. https://doi.org/10.30476/jha.2020.80242.1252 13. Suresh, M., Srividya, R., \& Kumaraswamy, S. (2021). Modelling the Factors of Job Stress in Audit Firms: A TISM Approach. In Advances in Materials Research (pp. 819-829). Springer, Singapore. https://doi.org/10.1007/978-98115-8319-3_82

Received 8.10.2020

Received in revised form 18.11.2020

Accepted 22.11.2020

Available online 28.02.2021 